\title{
Semiquantitative Analysis of the Expression of GABA-A Receptor Subunits in the Developing Embryonic Chick Brain Stem
}

\author{
Koh-ichi ENOMOTO, Hiroko KATAOKA*, and Akihiko HIROTA \\ Department of Physiology and *Department of Orthopedics, Shimane Medical University, \\ Izumo, 693-8501 Japan
}

\begin{abstract}
The expression levels of seven types of gamma-aminobutyric acid-A (GABA-A) receptor subunits $(\alpha 1, \beta 2, \beta 3, \beta 4, \gamma 1, \gamma 2$, and $\gamma 4)$ were quantified in the embryonic chick brain stem at 2 to $20 \mathrm{~d}$ of incubation (E2 to E20) and just after hatching. The expression level of mRNA was measured by using semiquantitative reverse transcription-polymerase chain reaction (RT-PCR). When property regions were amplified, two products were observed for each of the $\beta 2, \beta 4$, and $\gamma 2$ subunits because of alternative splicing. These were named $\beta 2 S$ and $\beta 2 L, \beta 4 S$ and $\beta 4 \mathrm{~L}$, and $\gamma 2 \mathrm{~S}$ and $\gamma 2 \mathrm{~L}$ for shorter and longer
\end{abstract}

fragments, respectively. Transcripts of $\alpha 1, \beta 2 \mathrm{~L}$, $\beta 2 S, \beta 3, \beta 4 \mathrm{~L}, \beta 4 \mathrm{~S}, \gamma 1$, and $\gamma 2 \mathrm{~S}$ subunits were first detected from E2 to E5 brain stems. The expression level of each subunit increased gradually with development and reached a plateau at E9 to E12. In contrast, a delay occurred in the appearance of both the $\gamma 4$ and $\gamma 2 \mathrm{~L}$ subunits, which were not detected until E8 to E10. The absence of $\gamma 4$ and/or $\gamma 2 \mathrm{~L}$ subunits may explain differences in the pharmacological characteristics of GABA-A receptors at the early stages of development. [Japanese Journal of Physiology, 51, 53-61, 2001]

Key words: GABA-A receptor subunit, alternative splicing, RT-PCR, developmental expression, embryonic brain stem.

GABA receptors are classified into two major groups: $\mathrm{Cl}^{-}$-channel ionotropic receptors (GABA-A and GABA-C receptors) $[1,2]$, and G-protein-coupled metabotropic receptors (GABA-B receptor) [3, 4]. In the central nervous system, ionotropic and metabotropic GABA receptors cause fast and slow postsynaptic potential changes, respectively [3, 4]. GABA-A and GABA-C receptors can be pharmacologically distinguished by their differential sensitivity to benzodiazepines and barbiturates $[1,2,5]$.

The GABA-A receptor is a pentamer composed of five subunits. Each subunit consisted from over 15 types, and different subunit compositions may produce significant differences in receptor properties [6-9]. In fact, in the 7-d-old chick brain stem, a pharmacological different GABA-A receptor has been reported [10]. However, qualitative and/or quantitative changes in GABA-A receptor subunits during the early stages of development have not been well documented. In the present study, we investigated the developmental changes in the expression levels of mRNA coding GABA-A receptor subunits in embryos at 2 to $20 \mathrm{~d}$ of incubation (E2 to E20) and just after hatching, using a semiquantitative reverse transcription-polymerase chain reaction (RT-PCR).

\section{MATERIALS AND METHODS}

Preparation and dissections. Fertilized chicken eggs (Barred Plymouth Rock) were incubated in a forced draft incubator (Type Baby (B), Showa Incubator Lab.) at $38^{\circ} \mathrm{C}$ and $60 \%$ humidity and were turned once an hour. The embryos were isolated at E2 to E18, and the brain stems were dissected under a binocular microscope. The brain stem is defined as the caudal part of the brain from the boundary between

Received on October 4, 2000; accepted on December 1, 2000

Correspondence should be addressed to: Koh-ichi Enomoto, Department of Physiology, Shimane Medical University, Izumo, 693-8501 Japan. Tel: +81-853-23-2111 ext 5181, Fax: +81-853-20-2115, E-mail: kenomoto@shimane-med.ac.jp 
the prosencephalon (diencephalon) and the mesencephalon. At the early stages of development, rhombencephalon and mesencephalon were dissected. After the cerebellum became identifiable, the cerebellum and possibly a large part of the cerebellar peduncle were removed.

Extraction of total RNA and RT-PCR. Immediately after the dissection, total RNA was extracted and purified from brain stems by using an RNA isolation kit (QIAGEN). To improve the quality of RNA sample, extracted RNA was retreated with same kit. To test the quality of the extracted RNA, agarose-gel electrophoresis was carried out for all samples, and the integrity of $18 \mathrm{~S}$ and $28 \mathrm{~S}$ ribosomal RNAs was confirmed. The contamination of genome DNA in the RNA sample was tested with PCR amplification of $\beta$-actin fragment without a reverse transcription step. Since no amplification was detected, it was confirmed that the contamination had practically no effect on the following experiments. A master mixture of cDNA was synthesized from total RNA, using MuLV reverse transcriptase (Perkin Elmer) and a random hexamer. The experimental process basically followed the manufacturer's protocol, except that the reaction mixture was incubated for 4 to $12 \mathrm{~h}$ at $37^{\circ} \mathrm{C}$. The quality of cDNA was tested by PCR, using $\beta$ actin primers (Table 1) [11]. Since DNA fragments of the expected length for amplified $\beta$-actin were detected in all samples (data not shown), it was concluded that the master mixture was adequately prepared.

The qualitative PCR was conducted by using a portion of the master mixture as a template and a primer pair specific to each subunit. Taq Gold DNA polymerase (Perkin Elmer) and premix Taq (TaKaRa) or Ready-To-Go PCR beads (Amersham) were used. The PCR consisted of 35 cycles of $30 \mathrm{~s}$ at $94^{\circ} \mathrm{C}, 30 \mathrm{~s}$ at a fixed temperature $\left(54\right.$ to $\left.62^{\circ} \mathrm{C}\right)$ and $45 \mathrm{~s}$ at $72^{\circ} \mathrm{C}$. Primer pairs specific for each subunit were designed based on the nucleotide sequences cited in the following references: $\alpha 1$ [12], $\beta 2$ [13, 14], $\beta 3$ [15], $\beta 4$ [16, 17], $\gamma 1$ [18], $\gamma 2$ [19], and $\gamma 4$ [20] (Table 1). In this paper, an underlined subunit name, e.g., $\beta 2$, represents the primer pair for the subunit. In an adult chicken, alternative splicing occurs in the mRNA of $\beta 2, \beta 4$, and $\gamma 2$ subunits. We have thus designated the primer pairs that include the splicing sites within the amplified area of the mRNAs as $\beta 2 \mathrm{SL}, \beta 4 \mathrm{SL}$, or $\underline{\gamma 2 S L}$, respectively. Two different sets of primer pairs were designed for the $\beta 2$ and $\beta 4$ subunits, one that in cluded the splicing sites, designated $\beta 2 \mathrm{SL}$ and $\beta 4 \mathrm{SL}$, and one that excluded these sites, designated $\overline{\beta 2}$ or $\underline{\beta 4}$.
DNA sequencing. The mRNA from embryos at E8 to E9 was used as a template. When a single fragment was amplified by RT-PCR, cDNA was purified from the reaction mixture by using a Microcon 100 (Amicon) and directly sequenced. To determine the sequence of fragments involving splicing sites ( $\beta 2 \mathrm{~S}, \beta 2 \mathrm{~L}, \beta 4 \mathrm{~S}, \beta 4 \mathrm{~L}$, and $\gamma 2 \mathrm{~L}$ subunits), amplified DNA fragments were separated by using agarose gel electrophoresis and purified with SUPREC-01 $(\mathrm{TaKaRa})$. These fragments were cloned into a plasmid vector, pCRII-TOPO, by a TOPO-TA cloning kit (Invitrogen). Plasmid DNA was prepared by using a Miniprep kit (Promega) and sequenced by using a dideoxy terminator cycle sequencing kit (Applied Biosystems and Amersham) and a DNA sequencer Model 377 (Applied Biosystems).

Semi-quantitative RT-PCR. To quantify the amount of mRNA, amplified fragments of GABA-A receptor cDNA were compared with internal $\beta$-actin cDNA. $\beta$-Actin is a housekeeping protein, and the level of $\beta$-actin mRNA should be consistent among cells throughout the tested developmental stages. Thus the ratio of GABA-A subunit PCR products to $\beta$-actin PCR products was proportional to the concentration of GABA-A receptor subunit mRNA [11,21]. To obtain a linear relationship between the amount of mRNA and PCR product, a suitable PCR cycle number and annealing temperature (i.e., $30 \mathrm{~s}$ at $94^{\circ} \mathrm{C}, 30 \mathrm{~s}$ at $54^{\circ} \mathrm{C}$, and $45 \mathrm{~s}$ at $72^{\circ} \mathrm{C}$ for 22 cycles) were selected for semiquantitative experiments. After electrophoresis, agarose or polyacrylamide gels were stained with SYBR gold (Molecular Probes) or ethidium bromide and photographed by a CCD camera with UV transillumination. The $\gamma$-compensation of the camera was set at 1 to ensure a linear relationship between the band intensity on the photo and the amount of PCR product, and care was taken to avoid the saturation of any bands on the image. The band intensity on the photocopy was then digitized with a density scanner, and the ratio of the band intensity of each GABA-A subunit to $\beta$-actin was calculated. The ratios for each subunit were then normalized to the highest observed ratio for that subunit. Experiments were repeated 2 to 11 times, and the mean \pm SE are shown.

Computer programs for DNA sequence analysis. Primers were designed by consulting PC-rare [22]. Sequence analysis and alignments were conducted with seqaid (Rhoads, D. D. and Roufa, D. J. (1991); the freeware program was obtained at http://mama.indstate.edu/pfaffle/software/) and macaw [23]. The densities of photocopies of gel patterns were measured by using BAG2000 (Inohara, N. (1996); the shareware program was obtained at fbio.Nifty-serve). 
Antheprot [24] was used to analyze protein structures and to search phosphorylation sites in deduced amino acid sequences.

\section{RESULTS}

\section{Nucleotide sequence of RT-PCR products}

Figure 1A shows typical electrophoresis patterns of the PCR products using specific primer pairs for GABA-A receptor $\alpha 1, \beta 3, \gamma 1$, and $\gamma 4$ subunits. Each DNA fragment exhibited a single band in all the tested developmental stages. A single band was also obtained with primer pairs $\beta 2$ and $\beta 4$ (data not shown). Alternative splicing has been reported in GABA-A receptor $\beta 2, \beta 4$, and $\gamma 2$ subunits in adult chicken $[3,4$, $7,9,16,25]$. The $\beta 2 \mathrm{SL}, \beta 4 \mathrm{SL}$, and $\gamma 2 \mathrm{SL}$ primer pairs were thus designed to contain these splicing sites (see MATERIALS AND METHODS), and double bands appeared with such primer pairs as expected. Double bands (short and long sequences, respectively) were thus observed with $\beta 2 \mathrm{SL}$ (designated $\beta 2 \mathrm{~S}$ and $\beta 2 \mathrm{~L}$ ), $\beta 4 \mathrm{SL}$ (designated $\beta 4 \mathrm{~S}$ and $\beta 4 \mathrm{~L}$ ), and $\gamma 2 \mathrm{SL}$ (designated $\gamma 2 S$ and $\gamma 2 L$; Figs. 2-4). The length of the fragments agreed with those predicted from published values, including the lost base pairs as a result of the alternative splicing (Table 1).

To confirm the accuracy of the PCR, the nucleotide sequences of the PCR products were determined and compared with published sequences. A few differ- ences were found in the fragments from the $\alpha 1, \beta 2$, $\beta 4$, and $\gamma 1$ subunits, but the sequences of the $\beta 3, \gamma 2$, and $\gamma 4$ fragments were identical to the published reports (Table 2). Furthermore, the splicing sites of $\beta 2$, $\beta 4$, and $\gamma 2$ exactly matched previously reported sequences $[3-7,9,17]$. From these results, we conclude that the PCR amplified the correct segments of the GABA-A receptor subunits.

\section{Expression of $\alpha 1, \beta 3, \gamma 1$, and $\gamma 4$ subunits during development}

The electrophoresis patterns of the RT-PCR products of $\alpha 1, \beta 3, \gamma 1$, and $\gamma 4$ subunits are illustrated in Fig. 1A, lanes a to d. In $\alpha 1, \beta 3$, and $\gamma 1$, a single band was detected at E2 or E3 (Fig. 1A, lanes a to c). There was a distinct delay in the time of appearance of the $\gamma 4$ subunit: only slight traces could be detected from embryos younger than E7, and the expression clearly increased after that stage (Fig. 1A, lane d).

The early onset of $\alpha 1, \beta 3$, and $\gamma 1$ fragments and the delayed appearance of $\gamma 4$ were confirmed by semiquantitative RT-PCR (Fig. 1B). An expression of the $\alpha 1, \beta 3$, or $\gamma 1$ subunits also started at E2 to E6 (Fig. 1B), but $\gamma 4$ appeared first at E9.

The results of the semiquantitative analysis of these subunits at each developmental stage are summarized in Fig. 1C. The expression of $\alpha 1, \beta 3$, and $\gamma 1$ subunits started from E2 to E4. The expression level increased gradually as development proceeded and reached a

Table 1. Primer pairs and length of PCR products.

\begin{tabular}{|c|c|c|c|c|}
\hline Primer & Target & Sequence & Location & $\begin{array}{l}\text { Amplified sequence } \\
\text { (bp) }\end{array}$ \\
\hline Actin & $\beta$-Actin & $\begin{array}{l}\text { CGGAACCGCTCATTGCC } \\
\text { ACCCACACTGTGCCCATCTA }\end{array}$ & & 289 \\
\hline$\alpha 1$ & $\alpha 1$ & $\begin{array}{l}\text { GACTTATCTGCCATGCATCATG } \\
\text { TAAATAGGTGGCCCAATAGAC }\end{array}$ & $961-1519$ & 559 \\
\hline$\beta 2$ & $\beta 2$ & $\begin{array}{l}\text { GATTGAGAGCTATGGCTATACGAC } \\
\text { CCTTATTGACATCCATTCGCAACT }\end{array}$ & $722-1268$ & 547 \\
\hline$\beta 2 S L$ & $\beta 2$ & $\begin{array}{l}\text { CAACAATTAACACTCATCTTCGAG } \\
\text { GTAAGCCAGCTTTCCGGTATTGGA }\end{array}$ & $1046-1467$ & 422,371 \\
\hline$\beta 3$ & $\beta 3$ & $\begin{array}{l}\text { GAGAGGTGGAGATAATGCGG } \\
\text { TAAGGCCAAGAAGACGAATA }\end{array}$ & 670-1054 & 385 \\
\hline$\beta 4$ & $\beta 4$ & $\begin{array}{l}\text { CTGACTGGGGGGGGTCGGTT } \\
\text { GTTGAGAGGAAGGTCGTTAT }\end{array}$ & $93-529$ & 437 \\
\hline$\beta 4 S L$ & $\beta 4$ & $\begin{array}{l}\text { CAGAAGAAACAGAGTGAACG } \\
\text { AGGACATGACAGAGTTTCGA }\end{array}$ & 1228-1416 & 189,177 \\
\hline$\underline{\gamma 1}$ & $\gamma 1$ & $\begin{array}{l}\text { AGCTTCATAACTTTCCTATGG } \\
\text { TAGATAAAGATAGCCAATCC }\end{array}$ & $560-1394^{*}$ & 835 \\
\hline$\underline{\gamma 2 S L}$ & $\gamma 2$ & $\begin{array}{l}\text { TGACCACCCTAAGTACGATT } \\
\text { CATGCTCCTGTTCGACAATC }\end{array}$ & $1611-1977$ & 367,343 \\
\hline$\underline{\gamma 4}$ & $\gamma 4$ & $\begin{array}{l}\text { TATCGATGTGGATATCTACG } \\
\text { GACCTCAATGGAATAGCGTC }\end{array}$ & $310-723$ & 414 \\
\hline
\end{tabular}

Primer pairs are shown with underlines. * Recalculated from sequence data in Greka et al. [5]. 


\section{Embryonic Days}

A
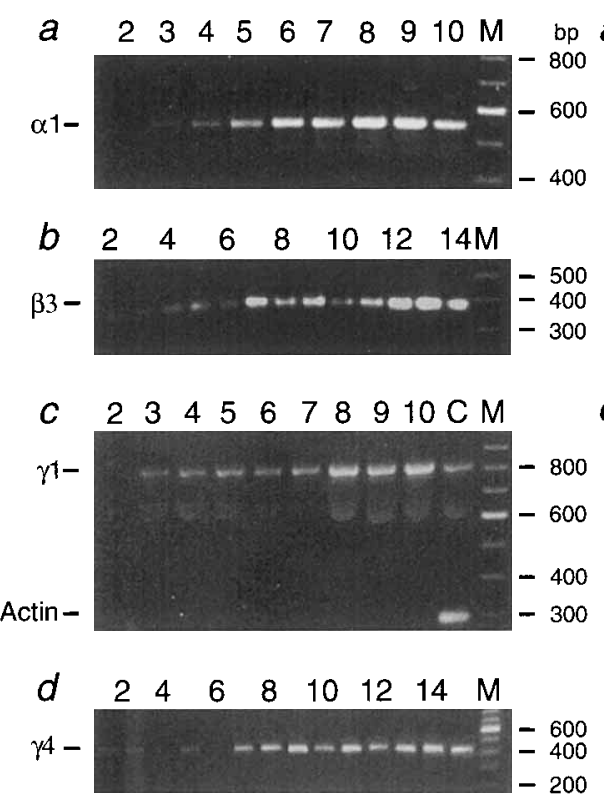

B

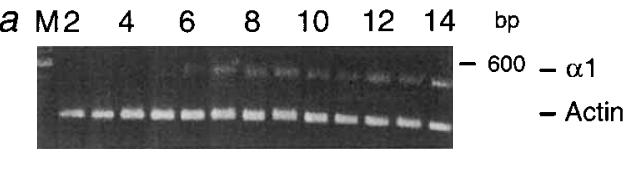

$\begin{array}{lllllll}b \mathrm{M} 2 & 4 & 6 & 8 & 10 & 12 & 14 \mathrm{M}\end{array}$

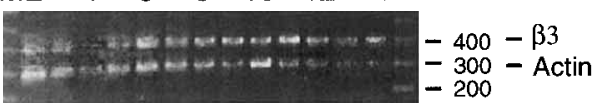

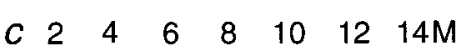

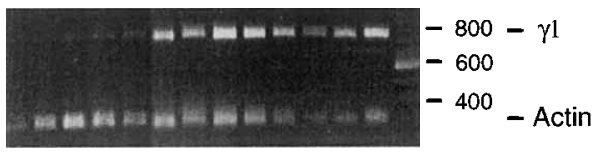

$\begin{array}{lllllllll}d & 2 & 4 & 6 & 8 & 10 & 12 & 14 & \mathrm{M}\end{array}$

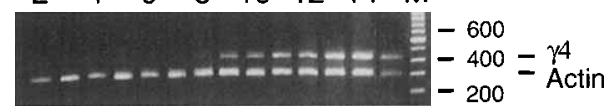

C

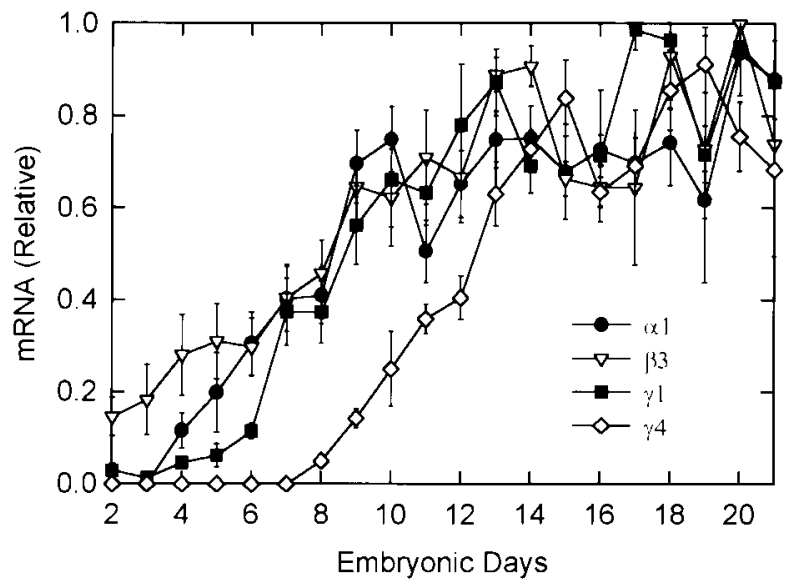

Fig. 1. Expression pattern of the $\alpha 1, \beta 3, \gamma 1$, and $\gamma 4$ GABA-A receptor subunit mRNAs during development in the embryonic chick brain stem analyzed by RT-PCR. The GABA-A receptor subunits that did not exhibit alternative splicing are summarized. $M$ is a DNA marker and numerals indicate the embryonic days. A: Typical agarose gel electrophoresis patterns of GABAA receptor subunits at E2 to E10 or E14. $\alpha 1, \beta 3, \gamma 1$, and $\gamma 4$ subunits are shown in lanes $a-d$, respectively. $X$ in lane $c$ shows the PCR products obtained with both $\gamma 1$ and $\beta$-actin (Actin). B: Electrophoresis patterns of RT-PCR products using the $\alpha 1, \beta 3, \gamma 1$, and $\gamma 4$ primer pairs in the presence of $\beta$-actin. $\alpha 1, \beta 3, \gamma 1$, and $\gamma 4$ subunits are shown in lanes $a-d$, respectively. c: Time course of the expression level of $\alpha 1$ (filled circle), $\beta 3$ (open inverted triangle), $\gamma 1$ (filled square), and $\gamma 4$ (diamond) GABA-A receptor subunit mRNA. Data were obtained from Fig. 1B and other similar experiments. In this and the subsequent figures, the ratio of the band intensity of each subunit to that of $\beta$-actin was calculated in each assay, and the ratios for each subunit were normalized to the highest observed ratio for that subunit.

plateau at E9 to E12. In contrast, the $\gamma 4$ subunit exhibited a late onset in expression. It was first detected at E8, and the expression level reached a plateau at E14.

\section{Expression of $\beta 2$ and $\beta 4$ subunits during de- velopment}

RT-PCR with the $\beta 2$ SL primer pair amplified double fragments $(\beta 2 S$ and $\beta 2 \mathrm{~L}$ for short and long sequences, respectively) because of alternative splicing (Table 2). Both fragments were already present at E3 (Fig. 2A). Since the densities of both bands increased together, it seems that the expression of $\beta 2 \mathrm{~S}$ and $\beta 2 \mathrm{~L}$ subunits started simultaneously and increased at simi- lar rates. Figure 2B shows a typical electrophoresis pattern of fragments obtained by using semiquantitative RT-PCR with $\beta 2$ SL and $\beta$-actin primer pairs. Again, the $\beta 2 S$ and $\beta 2 \mathrm{~L}$ subunits increased with a similar time course. The developmental expression of $\beta 2 \mathrm{~S}$ and $\beta 2 \mathrm{~L}$ is summarized in Fig. 2C. PCR with the $\beta 2$ primer amplified a segment of the $\beta 2$ subunit mRNA lacking the splicing site and yielded a single band. The temporal expression pattern of this fragment was identical to those observed with the $\beta 2 \mathrm{SL}$ primer.

A similar tendency was observed in the experiments using $\beta 4 \mathrm{SL}$ and $\beta 4$. Double bands $(\beta 4 \mathrm{~S}$ and $\beta 4 \mathrm{~L}$ for short and long fragments, respectively) were 
Table 2. Comparison of observed nucleotide sequence and reference in GABA-A receptor subunits in the chick.

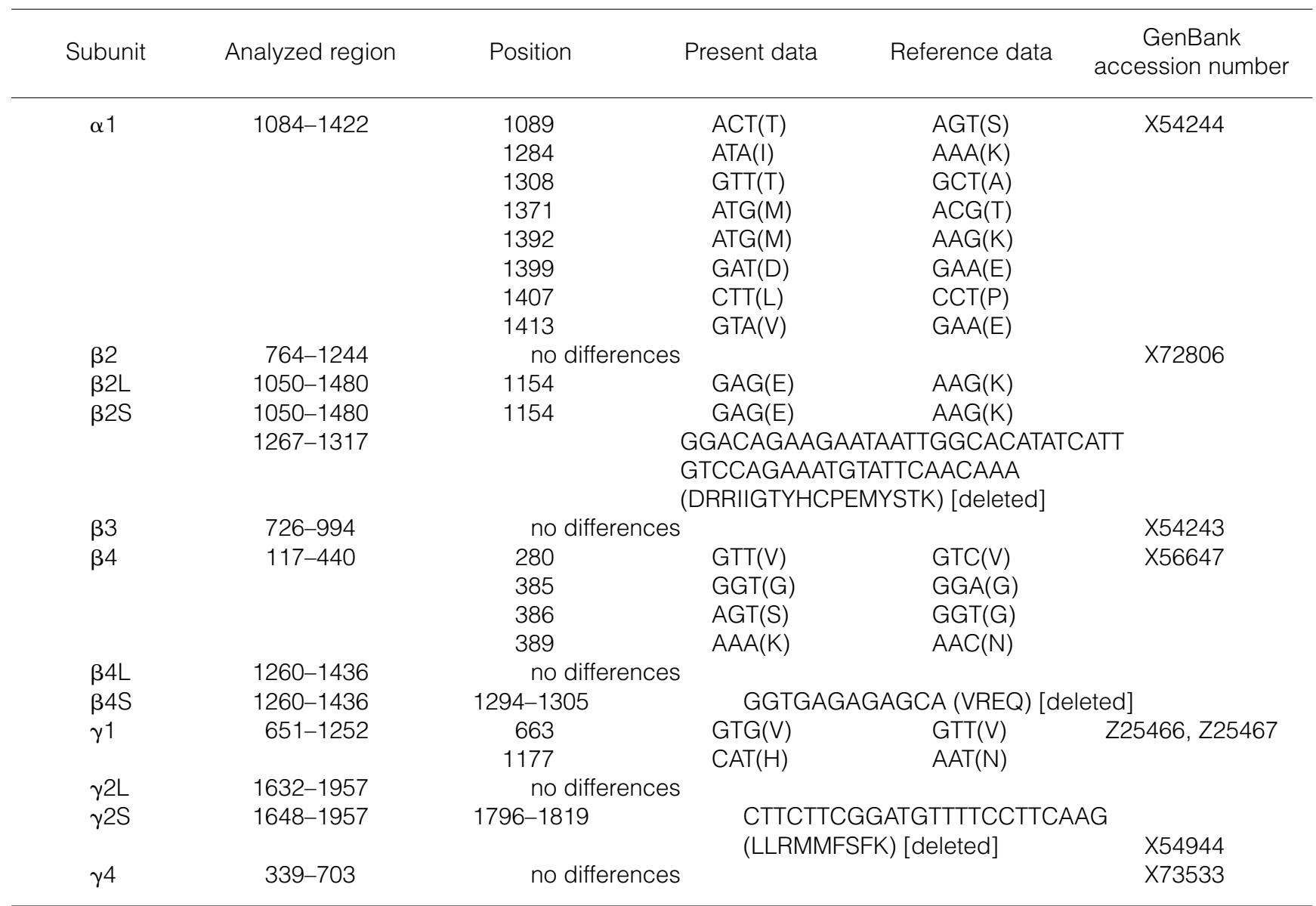

Letters in parentheses indicate corresponding amino acid sequence.

\section{Embryonic Days}
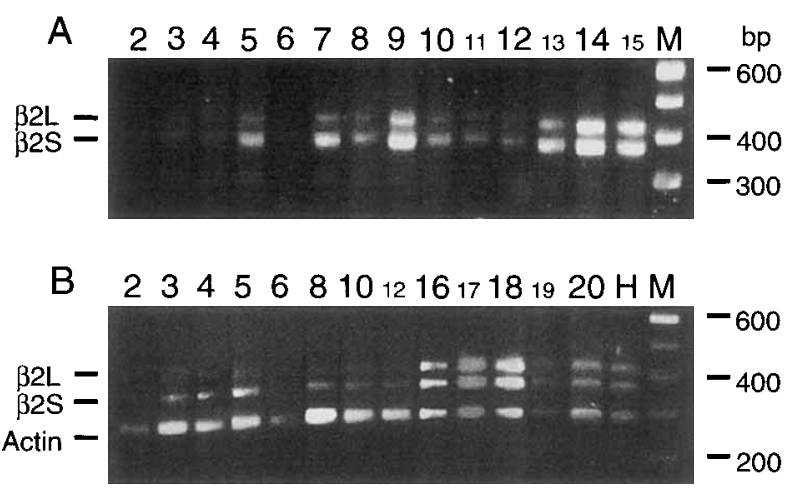

C

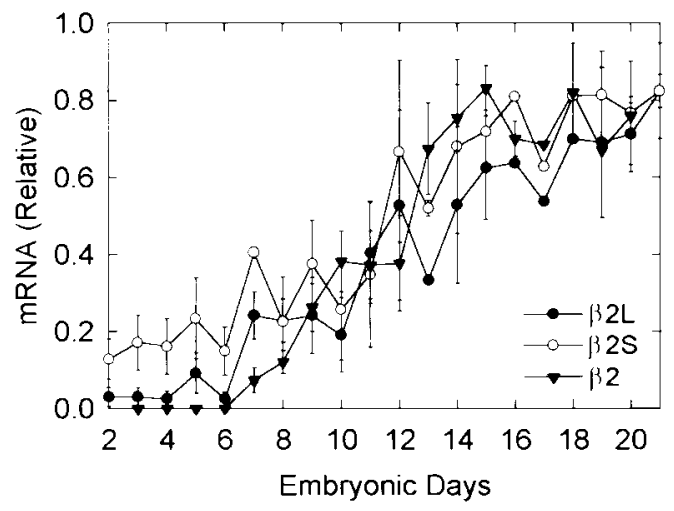

Fig. 2. Expression pattern of the $\boldsymbol{\beta} 2$ GABA-A receptor fragments ( $\beta 2 \mathrm{~L}, \beta 2 \mathrm{~S}$, and $\beta$-actin (Actin)) were observed subunit mRNA during development in the embryonic chick brain stem analyzed by RT-PCR. A: Typical agarose gel electrophoresis patterns of fragments of $\beta 2$ subunits amplified using the $\beta 2 S L$ primer pair. RT-PCR with $\beta 2 S L$ produced double bands, since 51 base pairs were spliced between the primer pair. An analysis of the nucleotide sequences confirmed that these represented fragments of the with RT-PCR using primer pairs of both $\beta 2 S L$ and $\beta$-actin. $\mathrm{H}$ indicates the developmental stage just $\overline{\text { after }}$ hatching. $\mathbf{C}$ : Developmental expression of mRNA coding GABA-A receptor $\beta 2 \mathrm{~L}$ (filled circle), $\beta 2 S$ (open circle), and total $\beta 2$ mRNA from a region in which alternative splicing was not present (filled inverted triangle). Data were obtained from Fig. 2B and similar experiments. 


\section{Embryonic Days}

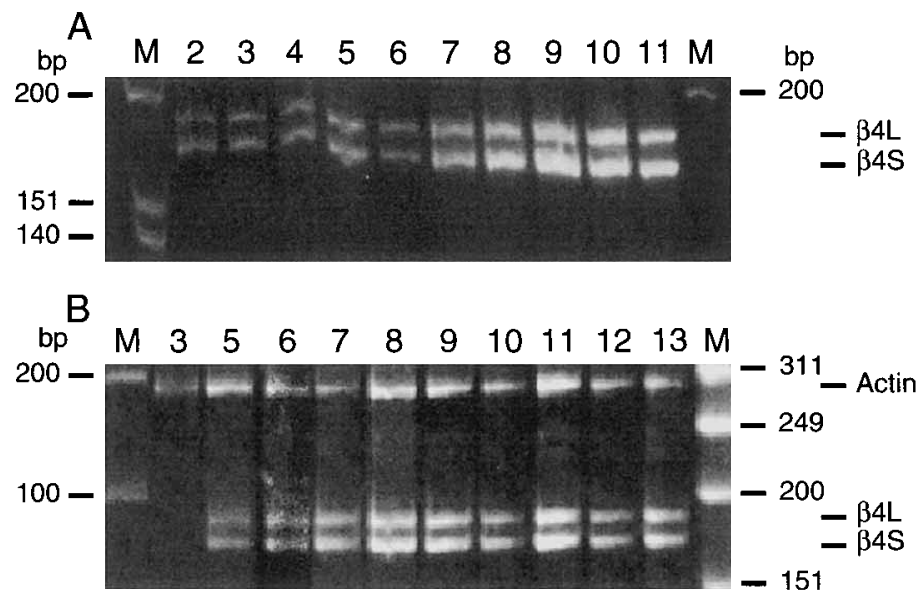

C

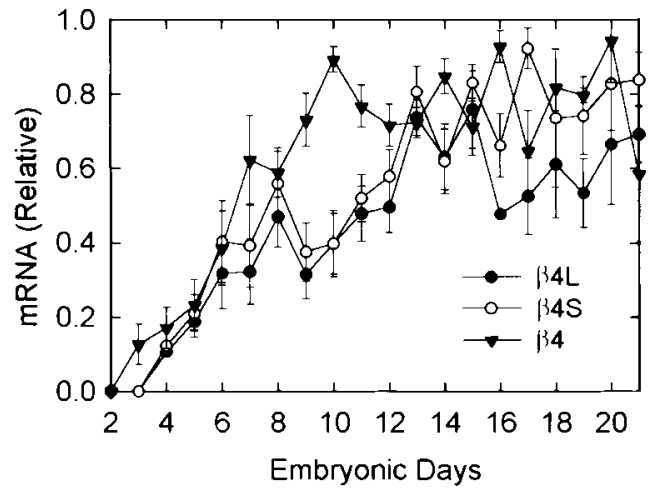

Fig. 3. Expression pattern of the $\beta 4$ GABA-A receptor subunits with $(\beta 4 S)$ and without $(\beta 4 L)$ splicing. B: Three subunit mRNA during development in the embryonic fragments ( $\beta 4 \mathrm{~L}, \beta 4 \mathrm{~S}$, and $\beta$-actin (Actin)) were observed chick brain stem analyzed by RT-PCR. A: Typical poly- with RT-PCR using both $\beta 4 S L$ and $\beta$-actin. C: Developacrylamide gel electrophoresis patterns of DNA fragments of the $\beta 4$ subunit amplified using the $\beta 4 S L$ primer pair. An alternatively spliced region 12 base pairs long was present between the primer pair. An analysis of the nucleotide sequence confirmed that these were $\beta 4$ GABA-A receptor mental expression of $\beta 4 \mathrm{~L}$ (filled circle) and $\beta 4 S$ (open circle) subunits and a region in which alternative splicing was not present (filled inverted triangle). Data were obtained from Fig. 3B and similar experiments.
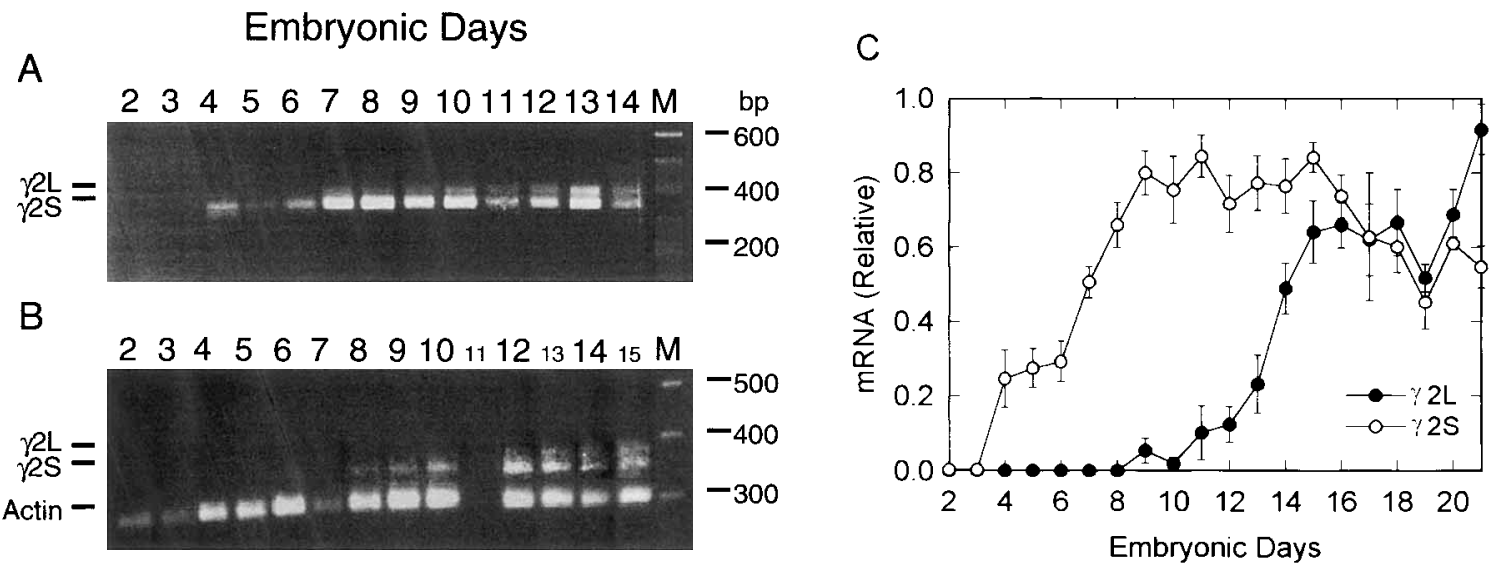

Fig. 4. Expression pattern of the $\gamma^{2}$ GABA-A receptor subunit during development in the embryonic chick brain stem analyzed by RT-PCR. A: Typical agarose gel electrophoresis patterns of PCR products of the $\gamma 2$ subunit using the $y 2 S L$ primer pair. An alternatively spliced region, which deleted 24 base pairs, was present between the primer pair. An analysis of the nucleotide sequence con-

observed with $\beta 4 \mathrm{SL}$. Both bands were first detected at $\mathrm{E} 2$ in the qualitative experiments (Fig. 3A) and at E5 in the semiquantitative one (Fig. 3B). The time course of expression of the $\beta 4$ fragment (amplified with $\beta 4$ ) was the same as the $\beta 4 \mathrm{~S}$ and $\beta 4 \mathrm{~L}$ fragments (electrophoresis data not shown). Figure $3 \mathrm{C}$ summarizes the time courses of developmental expression of the $\beta 4$ subunit in three different fragments. The temporal expression patterns of these three fragments were also identical. From Figs. 1C, 2C, and 3C, it can be con- firmed that these were the $\gamma 2$ GABA-A receptor subunits with $(\gamma 2 S)$ and without $(\gamma 2 \mathrm{~L})$ splicing. B: Three fragments ( $\gamma 2 \mathrm{~S}, \gamma 2 \mathrm{~L}$, and $\beta$-actin (Actin)) were observed with RT-PCR using both $\gamma 2 S L$ and $\beta$-actin. C: Developmental expression of GABA-A receptor $\gamma 2 \mathrm{~L}$ (filled circle) and $\gamma 2 S$ (open circle) subunits. Data were obtained from Fig. 4B and similar experiments.

cluded that the time course of expression of the $\alpha 1$, $\beta 3, \beta 2, \beta 4$, and $\gamma 1$ fragments were similar, but $\beta 4$ differed.

\section{Expression of the $\gamma 2$ subunit during develop- ment}

Figure 4A shows the results of qualitative PCR with ү2SL. In brain stems at E4 to E7, only a single band was detected. However, after E8, another fragment with a higher molecular weight appeared. Similar re- 
sults were obtained by using semiquantitative RT-PCR (Fig. 4B). The shorter fragment $(\gamma 2 S)$ appeared much earlier than the longer one $(\gamma 2 \mathrm{~L})$. Figure $4 \mathrm{C}$ summarizes the time courses of the developmental expression of $\gamma 2 \mathrm{~S}$ and $\gamma 2 \mathrm{~L}$ subunits. $\gamma 2 \mathrm{~S}$ was first detected at E4; the expression level increased gradually and reached a plateau at E9. On the other hand, $\gamma 2 \mathrm{~L}$ first appeared at E9 and reached a plateau at E15. Thus the temporal expression pattern of $\gamma 2 \mathrm{~S}$ resembled the early appearance group which included the $\alpha 1, \beta 3, \beta 2, \beta 4$, and $\gamma 1$ genes. In contrast, the time course of expression of $\gamma 2 \mathrm{~L}$ was similar to that of $\gamma 4$, and these belonged to the late expression group. It should be noted that the subunits belonging to the late expression group were absent in embryonic brain stem younger than E8.

\section{DISCUSSION}

The GABA-A receptor $/ \mathrm{Cl}^{-}$channel complex is a transmembrane protein consisting of five subunits selected from a pool of more than 15 [6-9]. GABA-A receptors in the central nervous system may have different characteristics because of their different subunit combinations. There is a correlation between the spatio-temporal expression patterns of subunit mRNAs and subunit proteins [6]. Differences in neuron-specific gene expression of GABA-A receptor subunits can explain the diversity of GABA-A receptor properties, such as the difference in benzodiazepine potentiation of the response to GABA [8].

To evaluate the developmental time course of gene expression of GABA-A receptor subunits, we used a semiquantitative RT-PCR technique to measure the amount of mRNA at different stages of development. We did not examine the quantity of GABA-A receptor proteins. Miranda et al. [26] reported a good correlation between the level of GABA-A receptor $\alpha 1$ subunit mRNA and $\alpha 1$ polypeptide in the embryonic chick cerebral cortex. It is very likely that the amount of mRNA coding other GABA-A receptor subunits is also proportional to that of the synthesized proteins.

Our results indicate that the expression of the $\alpha 1$, $\beta 2 \mathrm{~S}, \beta 2 \mathrm{~L}, \beta 3, \beta 4 \mathrm{~S}, \beta 4 \mathrm{~L}, \gamma 1$, and $\gamma 2 \mathrm{~S}$ subunits started in the early stage of embryogenesis. The mRNA of these subunits could be detected as early as E2 to E5 (Figs. 1-4). A time lag occurred in the appearance of the $\gamma 2 \mathrm{~L}$ and $\gamma 4$ subunits. They appeared first at E8 to E10 (Figs. 1 and 4). Thus in the embryonic chick brain stem younger than $\mathrm{E} 8$, both $\gamma 2 \mathrm{~L}$ and $\gamma 4$ subunits are lacking, but the $\alpha 1, \beta 2 \mathrm{~S}, \beta 2 \mathrm{~L}, \beta 3, \beta 4 \mathrm{~S}, \beta 4 \mathrm{~L}, \gamma 1$, and $\gamma 2 \mathrm{~S}$ subunits are present. The absence of $\gamma 4$ and/or $\gamma 2 \mathrm{~L}$ subunits from GABA-A receptors might explain the existence of pharmacologically different
GABA receptors in the early stage of development [10].

In bovine, human, and rat brains, two subtypes of $\gamma 2$ subunits are known because of the alternative splicing of mRNA $[19,25]$ (Table 2). In $\gamma 2 \mathrm{~S}$, eight amino acids are missing relative to $\gamma 2 \mathrm{~L}$ (Table 2), including an "SFK" sequence that confers a phosphorylation site for protein kinase C (PKC) [25]. The $\gamma 2 \mathrm{~L}$ subunit can be phosphorylated at this site, and $\mathrm{PKC}$ activators can inactivate the GABA-A receptor [27]. Similar alternative splicing occurs in the $\beta 2$ subunit, which also includes a phosphorylation site within the splicing site $[3,4]$. This site $[3,16]$ is outside the alternatively spliced region in the $\beta 4$ subunit $[6,17]$. The alternative splicing of mRNA further increases the potential diversity of GABA-A receptor [27].

Tissue-specific quantitative differences in the expression of $\gamma 2 \mathrm{~S}$ and $\gamma 2 \mathrm{~L}$ have been reported. $\gamma 2 \mathrm{~S}$ was more prominent than $\gamma 2 \mathrm{~L}$ in the bovine cortex, whole human brain, and rat hippocampus, whereas $\gamma 2 \mathrm{~L}$ was dominant in the rat cortex, rat striatum, and rat cerebellum [17]. Whether tissue-specific expression patterns of spliced mRNA derivatives are in the brain stem remains to be elucidated. According to Glencorse et al. [28], in the nuclei of visual and auditory pathways in the chick brain at $1 \mathrm{~d}$ after hatching, $\gamma 1$ subunit transcripts are absent but $\gamma 2$ transcripts are present. Moreover, both $\alpha 1$ and $\gamma 2 \mathrm{~S}+\gamma 2 \mathrm{~L}$ transcripts are present in many brain regions in the same preparation [28]. Thus it is probable that mRNAs of various subunits localize to distinct brain regions and that there are varying degrees of overlap in their distribution patterns.

Using a multiple-site optical recording technique employing a fast voltage-sensitive dye, Momose-Sato et al. [10] found a novel type of GABA response in the embryonic brain stem slice preparation at E7-E8 stage. This GABA receptor was blocked by either GABA-A antagonists, including picrotoxin, dieldrin, bicuculine, and SR95531, or GABA-B antagonists, 2hydroxysaclofen, CGP35348, and phacofen. Furthermore, it is stimulated by either GABA-A or GABA-B agonists, musimol, and bacrofen. On the other hand, several investigators compared subtype specific single-channel properties, using gene expression in Xenopus oocyte [29], fibroblast cell line L929 [30, 31 , Chinese hamster ovary cells [32], or targeted disruption of the $\gamma 2$ subunit [33]. Sensitivity to GABA, single-channel conductance, and the number of open and closed states differ in combinations $\alpha 1 \beta 3, \alpha 1 \beta 3 \delta$, and $\alpha 1 \beta 3 \gamma 2$ subunits [30-32], or in wild and mutant mice lacking the $\gamma 2$ subunit [33]. They concluded that in GABA-A receptors, the $\gamma 2$ subunit enhances the ef- 
ficacy of GABA by prolonging the open channel lifetime [30-33]. Thus it is highly possible that the lack of a $\gamma$ subunit, such as $\gamma 4$ and $\gamma 2 \mathrm{~L}$, causes different characteristics in the GABA-A receptor, as occurred in the early stage of development (Figs. 1 and 4). In fact, in the GABA-A receptor consisted of $\alpha 1 \beta 1$ isoform, open duration increases with pentobarbital, and both open duration and opening frequency slightly reduce by the application of picrotoxin [32]. However, the pharmacological characteristics of GABA response without $\gamma$ subunit remain to be elucidated.

In the present study, we used chick brain stems at different developmental stages and showed that there were differences in the onset and alternative splicing of GABA-A receptor subunits. The expression of the $\alpha 1, \beta 2 \mathrm{~L}, \beta 2 \mathrm{~S}, \beta 3, \beta 4 \mathrm{~L}, \beta 4 \mathrm{~S}, \gamma 1$, and $\gamma 2 \mathrm{~S}$ subunits started early at E2 to E5, and the expression of the $\gamma 4$ and $\gamma 2 \mathrm{~L}$ subunits was delayed; they first appeared at E8 to E10. The absence of $\gamma 4$ and/or $\gamma 2 \mathrm{~L}$ subunits until E8 to E10 may explain the pharmacological differences in GABA response at this stage, which was observed by Momose-Sato et al. [10].

This work was supported in part by a Grant-in-Aid for Scientific Research from the Ministry of Education, Science, Sports and Culture of Japan (No. 08458269) and by a grant from Japan Society for the Promotion of Science (No. 12680796).

\section{REFERENCES}

1. Johnston GA: GABAc receptors: relatively simple transmitter-gated ion channels? Trends Pharmacol Sci 17: 319-323, 1996

2. Nelson R, Schaffner AE, Li YX, and Walton MK: Distribution of $\mathrm{GABA}(\mathrm{C})$ like responses among acutely dissociated rat retinal neurons. Vis Neurosci 16: 179-190, 1999

3. Castelli MP, Ingianni A, Stefanini E, and Gessa GL: Distribution of $\mathrm{GABA}(\mathrm{B})$ receptor mRNAs in the rat brain and peripheral organs. Life Sci 64: 1321-1328, 1999

4. Cunningham MD and Enna SJ: Evidence for pharmacologically distinct GABAB receptors associated with cAMP production in rat brain. Brain Res 720: 220-224, 1996

5. Greka A, Koolen JA, Lipton SA, and Zhang D: Cloning and characterization of mouse $\mathrm{GABA}(\mathrm{C})$ receptor subunits. Neuroreport 9: 229-232, 1998

6. Luscher B, Hauselmann R, Leitgeb S, Rulicke T, and Fritschy JM: Neuronal subtype-specific expression directed by the $G A B A(A)$ receptor delta subunit gene promoter/upstream region in transgenic mice and in cultured cells. Mol Brain Res 51: 197-211, 1997

7. Macdonald RL and Olsen RW: GABAA receptor channels. Annu Rev Neurosci 17: 569-602, 1994

8. McKernan RM and Whiting PJ: Which GABAA-receptor subtypes really occur in the brain? Trends Neurosci 19: 139-143, 1996
9. Schofield PR, Darlison MG, Fujita N, Burt DR, Stephenson $F A$, Rodriguez $H$, Rhee LM, Ramachandran J, Reale V, Glencorse TA, Seeburg PH, and Barnard EA: Sequence and functional expression of the GABAA receptor shows a ligand-gated receptor super-family. Nature 328: 221-227, 1987

10. Momose-Sato Y, Sato K, Hirota A, Sakai T, Yang XS, and Kamino K: Optical characterization of a novel GABA response in early embryonic chick brainstem. Neuroscience 80: 203-219, 1997

11. du Breuil RM, Patel JM, and Mendelow BV: Quantitation of beta-actin-specific mRNA transcripts using xeno-PCR. PCR Methods 3: 57-59, 1993

12. Bateson AN, Harvey RJ, Wisden W, Glencorse TA, Hicks AA, Hunt SP, Barnard EA, and Darlinson MG: The chicken GABA-A receptor alpha-1 subunit: cDNA sequence and localization of the corresponding mRNA. Mol Brain Res 9: 333-339, 1991 (GenBank accession number X54244)

13. Harvey RJ, Chinchetru MA, and Darlison MG: Alternative splicing of a 51-nucleotide exon that encodes a putative protein kinase $\mathrm{C}$ phosphorylation site generates two forms of the chicken gamma-aminobutyric acid A receptor beta 2 subunit. J Neurochem 62: 10-16, 1994 (GenBank accession number X72806, X72807)

14. Harvey RJ and Darlison MG: In situ hybridization localization of the GABAA receptor beta $2 \mathrm{~S}$ - and beta $2 \mathrm{~L}-$ subunit transcripts reveals cell-specific splicing of alternate cassette exons. Neuroscience 77: 361-369, 1997

15. Bateson AN, Harvey RJ, Bloks CC, and Darlison MG: Sequence of the chicken GABAA receptor beta 3-subunit cDNA. Nucleic Acids Res 18: 5557, 1990 (GenBank accession number X54243)

16. Bateson AN, Lasham A, and Darlison MG: Gammaaminobutyric acid-a receptor heterogeneity is increased by alternative splicing of a novel beta-subunit gene transcript 1990 (GenBank accession number X56647)

17. Liu SC, Parent L, Harvey RJ, Darlison MG, and Barnes EM Jr: Chicken GABA(A) receptor beta4 subunits form robust homomeric GABA-gated channels in Xenopus oocytes. Eur J Pharmacol 354: 253-259, 1988 (GenBank accession number X56646, X56647, X56648)

18. Glencorse TA, Darlison MG, Barnard EA, and Bateson AN: Sequence and novel distribution of the chicken homologue of the mammalian gamma-aminobutyric acidA receptor gamma 1 subunit. J Neurochem 61: 2294-2302, 1993 (GenBank accession number Z25466, Z25467)

19. Whiting PJ, McKernan RM, and Iversen LL: Another mechanism for creating diversity in gamma-aminobutyrate type A receptors: RNA splicing directs expression of two forms of gamma2 phosphorylation site. Proc Natl Acad Sci USA 87: 9966-9970, 1990

20. Harvey RJ, Kim HC, and Darlison MG: Molecular cloning reveals the existence of a fourth gamma subunit of the vertebrate brain GABAA receptor. FEBS Lett 331: 211-216, 1993 (GenBank accession number X73533)

21. Riedy MC, Timm EA, and Stewart CC: Quantitative RT- 


\section{Development of GABA-A Receptor Subunits}

PCR for measuring gene expression. Biotechniques 18: 70-74, 1995

22. Griffais R, Andre PM, and Thibon M: K-tuple frequency in the human genome and polymerase chain reaction. Nucleic Acids Res 19: 3887-3891, 1998 freeware program obtained at http://bioinformatics.weizmann.ac.il/ software/

23. Schuler GD, Altschul SF, and Lipman DJ: A workbench for multiple alignment construction and analysis. Proteins Struct Funct Genet 9: 180-190, 1991 freeware program obtained at http://ftp.bio.indiana.edu/molbio/ ibmpc/

24. Deleage G, Clerc FF, Roux B, and Gautheron DC: ANTHEPROT: a package for protein sequence analysis using a microcomputer. Cabios 4: 251-356, 1988 freeware program obtained at http://www.ibcp.fr/ ANTHEPROT/

25. Ashiya M, Zhang L, and Grabowski PJ: Regulated splicing of gamma2 pre-messenger RNA in neuronal cells. Nucleic Acids Symp Ser 33: 215-216, 1995

26. Miranda JD, Liu SC, Diaz ME, and Barnes Jr EM: Developmental expression of chick cortical GABA-A receptor $\alpha 1$ subunits in vivo and in vitro. Devel Brain Res 99: 176-186, 1997

27. McDonald BJ and Moss SJ: Conserved phosphorylation of the intracellular domains of $\mathrm{GABA}(\mathrm{A})$ receptor beta2 and beta3 subunits by CAMP-dependent protein kinase, cGMP-dependent protein kinase, protein ki- nase $\mathrm{C}$ and $\mathrm{Ca}^{2+}$ /calmodulin type II-dependent protein kinase. Neuropharmacology 36: 1377-1385, 1997

28. Glencorse TA, Bateson AN, and Darlison MG: Sequence and functional expression of the GABA A receptor shows a ligand-gated receptor super-family. Nucleic Acids Res 18: 7157, 1990

29. Malherbe P, Draguhn A, Multhaup G, Beyreuther K, and Mahler $\mathrm{H}$ : GABAA-receptor expressed from rat brain alpha- and beta-subunit cDNAs displays potentiation by benzodiazepine receptor ligands. Brain Res Mol Brain Res 8:199-208, 1990

30. Fisher JL and Macdonald RL: Single channel properties of recombinant GABAA receptors containing $\gamma 2$ or $\delta$ subtypes expressed with $\alpha 1$ and $\beta 3$ subtypes in mouse L929 cells. J Physiol (Lond) 505: 283-297, 1997

31. Haas KF and Macdonald RL: GABAA receptor subunit $\gamma 2$ and $\delta$ subtypes confer unique kinetic properties on recombinant GABAA receptor currents in mouse fibroblasts. J Physiol (Lond) 514: 27-45, 1999

32. Porter NM, Angelotti TP, Twyman RE, and Macdonald RL: Kinetic properties of $\alpha 1 \beta 1 \gamma$-aminobutyric acid A receptor channels expressed in chinese hamster ovary cells: regulation by pentobarbital and picrotoxin. Mol Pharmacol 42: 872-881, 1992

33. Lorez M, Benke D, Luscher B, Mohler H, and Benson JA: Single-channel properties of neuronal GABAA receptors from mice lacking the $\gamma 2$ subunit. J Physiol (Lond) 527: 11-31, 2000 